\title{
Penerapan Metode Kerja Kelompok dan Media Gambar untuk Meningkatkan Hasil Belajar Tematik Siswa di SD Negeri 2 Tete
}

\author{
Jaurah \\ SD Negeri 2 Tete, Kabupaten Tojo Una Una - Provinsi Sulawesi Tengah \\ Corresponding Author. Email: jaurahmunir64@gmail.com
}

\begin{abstract}
This study aims to improve students' thematic learning outcomes through the use of group work methods and image media. This study uses a classroom action research method. The subjects of this study were 23 students of class III SD Negeri 2 Tete. Data collection techniques using tests and observation sheets. Meanwhile, the data analysis technique used in this research was quantitative and qualitative descriptive analysis. Based on the results of the research that has been carried out, it can be concluded that students become more enthusiastic and motivated in thematic learning, data from cycle to cycle shows that student learning outcomes have increased. From $21.74 \%$ of students who completed to $56.52 \%$ in cycle 1 , then in cycle 2 increased to $100 \%$. Through the application of group work methods and image media in thematic learning can improve learning outcomes of grade III even semester SD Negeri 2 Tete with a $100 \%$ completeness percentage.
\end{abstract}

Abstrak: Penelitian ini bertujuan; (1) menganalisis pengaruh kompetensi pedagogik guru terhadap prestasi belajar siswa, (2) menganalisis pengaruh motivasi belajar terhadap prestasi siswa, (3) menganalisis pengaruh kompetensi pedagogik dan motivasi belajar siswa terhadap prestasi belajar siswa. Penelitian ini merupakan penelitian kuantitatif dengan menggunakan analisis regresi liner berganda. Penelitian ini menggunakan studi populasi dengan seluruh siswa XI TKJ SMKN 1 Trowulan yang berjumlah 60 siswa. Penelitian ini menggunakan angket dalam bentuk google form sebagai instrument untuk mempermudah pengambilan data. Dari hasil uji analisis regresi linear berganda dapat ditarik kesimpulan(1) kompetensi paedagogik berpengaruh terhadap prestasi belajar siswa; (2) motivasi belajar berpengaruh terhadap prestasi siswa, (3) kompetensi pedagogik dan motivasi belajar siswa berpengaruh terhadap prestasi belajar siswa.
Article History

Received: 29-01-2021

Revised: 10-03-2021

Published: 04-04-2021

Key Words:

Group Work, Image

Media, Learning

Outcomes, Thematic.

\section{Sejarah Artikel}

Diterima: 29-01-2021

Direvisi: 10-03-2021

Diterbitkan: 04-04-2021

\section{Kata Kunci:}

Prestasi Belajar, Kompetensi Paedagogik, Motivasi Belajar.

How to Cite: Jaurah, J. (2021). Penerapan Metode Kerja Kelompok dan Media Gambar untuk Meningkatkan Hasil Belajar Tematik Siswa di SD Negeri 2 Tete. Jurnal Paedagogy, 8(2). doi:https://doi.org/10.33394/jp.v8i2.3479

https://doi.org/10.33394/jp.v8i2.3479

This is an open-access article under the CC-BY-SA License.

\section{Pendahuluan}

Permasalahan yang dihadapi dalam dunia pendidikan cukup kompleks, mulai dari rendahnya kemampuan siswa dalam menyerap pembelajaran di kelas sehingga berdampak terhadap hasil evaluasai yang kurang memuaskan. Selain itu, rendahnya hasil belajar siswa dalam kelas yang disebabkan karena kualitas guru dalam memanfaatkan media dan metode yang inovatif masih rendah (Surodiana, 2020; Suarni, 2021; Nuryaningsih, 2021). Tujuan dalam proses pembelajaran memerlukan keterlibatan secara aktif siswa yang belajar. Namun dalam kenyataannya proses pembelajaran masih tampak adanya kecenderungan meminimalkan peran dan keterlibatan siswa.

Pembelajaran merupakan proses pengembangan ilmu-ilmu pengetahuan dan pengalaman, salah satunya adalah Tematik. Tematik sebagai salah satu ilmu yang tidak kalah pentingnya dalam upaya meningkatkan mutu kehidupan bangsa. Tematik merupakan 
salah satu mata pelajaran yang wajib dipelajari oleh para siswa di jenjang apapun di Indonesia. Pada pelaksanaannya, Tematik merupakan mata pelajaran yang sering membuat siswa tidak termotivasi untuk belajar.

Sementara itu, syarat yang terdapat dalam tujuan pengajaran Tematik belum sepenuhnya mendapat perhatian siswa, ini dibuktikan banyak siswa yang kurang memahami materi pada pelajaran Tematik, bahkan terkesan bagi siswa bahwa Tematik merupakan pelajaran yang membosankan. Dipihak lain dapat bersumber dari guru misalnya cara penyampaian atau penerapan yang kurang memberikan tugas kepada siswa atau hal-hal lain yang menyebabkan kurang berhasilnya proses belajar mengajar Tematik dan masalah lain yang terkait dengan Tematik.

Penerapan teori belajar pada pembelajaran yang sesuai di dalam pelaksanaan pembelajaran di kelas akan merangsang minat belajar sehingga hasil belajarnya meningkat. Salah satu teori belajar yang dapat digunakan untuk meningkatkan hasil belajar siswa pada pembelajaran Tematik melalui Metode Kerja Kelompok Dan Media Gambar (Achmad, 2018; Jayanti F, 2020; Papasi, 2020).

Model pembelajaran tematik pada hakikatnya merupakan model pembelajaran terpadu, yaitu suatu pendekatan pembelajaran yang memungkinkan peserta didik baik secara individual maupun kelompok aktif mencari, menggali, dan menemukan konsep serta prinsip secara holistik dan autentik. Melalui pembelajaran terpadu, peserta didik terlatih untuk dapat menemukan sendiri berbagai konsep yang dipelajari secara menyeluruh (holistik), bermakna, autentik, dan aktif. Dengan demikian, peserta didik dapat memperoleh pengalaman langsung sehingga dapat menambah kekuatan untuk menerima, menyimpan, dan menerapkan konsep yang telah dipelajarinya.terlatih untuk dapat menemukan sendiri berbagai konsep yang dipelajari secara menyeluruh (holistik), bermakna, autentik, dan aktif. Cara pengemasan pengalaman belajar yang dirancang guru sangat mempengaruhi pada pengalaman bagi para peserta didik. Pengalaman belajar yang lebih menunjukkan kaitan komponen-komponen konseptual akan menjadikan proses belajar lebih efektif.

Dalam pembelajaran tematik di Sekolah Dasar tidak sedikit yang dirasakan siswa sebagai beban. Banyak siswa yang mengeluh dan menyatakan bahwa Tematik itu sulit, sehingga pelajaran Tematik kurang menarik bagi siswa. Kalau siswa sudah tidak tertarik atau tidak berminat terhadap pelajaran Tematik, siswa tidak termotivasi belajar dan akibatnya nilai ulangan atau ujian menjadi rendah. Mereka selalu berpendapat nilai dibawah standar. Jika hal itu dibiarkan maka selamanya pelajaran Tematik kurang diminati siswa. Akhirnya akan berdampak pada kesulitan pembelajaran Tematik, sehingga nilai ulangan tidak memenuhi KKM (Kriteria Ketuntasan Minimal).

Pada umumnya tingkat pemahaman terhadap suatu mata pelajaran dinyatakan dengan nilai. Nilai yang tinggi menunjukkan bahwa siswa menguasai materi pelajaran sehingga proses pembelajaran dianggap telah berhasil. Sebaliknya nilai rendah yang diraih siswa menunjukkan bahwa pembelajaran belum berhasil. Hal tersebut terjadi di kelas yang peneliti alami yaitu di kelas III semester 2 SD Negeri 2 Tete. Dari hasil tes formatif, hanya ada 5 siswa yang memenuhi KKM.

Berbagai upaya pembelajaran telah dilakukan oleh peneliti untuk meningkatkan nilai prestasi Tematik terutama tema bumi dan alam semesta. Upaya pembelajaran itu diantaranya menyuruh siswa mengerjakan lembar kerja siswa, Menyuruh beberapa siswa untuk maju mengerjakan soal dari guru, dan memberikan PR kepada siswa. Namun semua itu belum dapat meningkatkan nilai hasil belajar siswa. Siswa justru merasa bosan dan tidak tertarik mengikuti pelajaran Tematik. 
Berdasarkan pengamatan yang dilakukan, rendahnya hasil belajar siswa pada kegiatan pembelajaran Tematik di sekolah ditemukan keragaman masalah sebagai berikut : (1) Keaktifan siswa dalam mengikuti pelajaran tidak tampak. Para siswa jarang sekali mengajukan idenya, walaupun guru berulang kali meminta agar siswa bertanya jika ada hal-hal yang belum dipahami; (2) Siswa mengalami kesulitan dalam memahami konsep bagian bumi dan alam semesta. Siswa sering belajar dengan cara menghafal tanpa membentuk pengertian terhadap materi yang dipelajari, hal ini menyebabkan rendahnya aktivitas siswa dalam belajar untuk menemukan sendiri konsep materi sehingga akan lebih cepat lupa; (3) Banyak siswa yang mengalami kesulitan dalam memecahkan masalah atau soal yang diberikan menyangkut bagian bumi dan alam semesta. Dalam menyelesaikan soal Tematik sering timbul kesulitan-kesulitan yang dialami oleh siswa. Kesulitan tersebut meliputi kesalahan dalam memahami soal dan kesalahan dalam melakukan perhitungan. Kesalahan pemahaman tersebut merupakan kesalahan siswa yang disebabkan ketidakmampuan siswa dalam memahami isi soal tersebut.

Berdasarkan hal tersebut maka dapat dilakukan tindakan-tindakan perbaikan pengajaran untuk meningkatkan hasil belajar siswa terhadap mata pelajaran Tematik khususnya tema bumi dan alam semesta melalui metode kerja kelompok dan media gambar, sehingga siswa dapat menunjukkan kemampuannya dalam pembelajaran Tematik, dan diharapkan siswa akan termotivasi untuk meningkatkan hasil belajarnya. Adapun tujuan penelitian ini adalah untuk meningkatkan hasil belajar tematik siswa melalui penerapan metode kerja kelompok dan media gambar pada tema bumi dan alam semesta.

\section{Metode Penelitian}

Metode penelitian ini menggunakan metode penelitian tindakan kelas. Subjek penelitian adalah siswa kelas III SD Negeri 2 Tete yang berjumlah 23 siswa. Data penelitian dikumpulkan menggunakan teknik tes, yaitu tes tertulis yang dilaksanakan pada akhir pelaksanaan pada kegiatan pembelajaran yaitu pada pra siklus, siklus I, dan siklus II. Disamping menggunakan butir-butir soal tentang mengenal Bagian bumi dan alam semesta dan ketampakan rupa bumi, juga menggunakan pengamatan proses pembelajaran yang dilakukan oleh teman sejawat sebagai observer berserta peneliti. Teknik analisis data penelitian ini menggunakan analisis deskriptif kuantitatif dan kualitatif. Data yang dikumpulkan berbentuk skor (kuantitatif), dianalisis untuk membandingkan nilai tes awal (pra siklus), nilai tes setelah siklus I dan nilai tes setelah siklus II. Perubahan nilai per siklusnya akan di proses untuk mengukur keberhasilan penerapan metode kerja kelompok dan media gambar.

\section{Hasil Penelitian dan Pembahasan Deskripsi Pra Siklus}

Kondisi awal ketika guru menerapkan metode ceramah dan penggunaan alat peraga dalam kelompok kecil adalah siswa tidak terlibat secara aktif hanya guru saja yang aktif. Hal ini dapat ditunjukkan dengan adanya siswa yang bicara sendiri, suasana dalam kelas menjadi gaduh, siswa tidak konsentrasi jika diberi pertanyaan tentang materi yang disampaikan sehingga tidak bisa menjawab pertanyaan, bahkan ada siswa yang bermain sendiri. Setelah diadakan tes evaluasi ternyata hasil belajarnya rendah yaitu nilai rata-rata kelasnya 61,30 (dibawah KKM 70). Pra siklus menggunakan data nilai dari mata pelajaran Tematik yang sudah ada tanpa melibatkan observer. 


\section{Deskripsi Siklus I}

Dari data pengamatan yang dilakukan observer diketahui bahwa guru dalam kegiatan pembelajaran diawali dengan memberi apersepsi yang mangarah ke materi yang diajarkan, menggunakan beberapa metode yaitu ceramah, diskusi, tanya jawab. Menggunakan alat peraga meskipun kecil dan menerapkan Metode Kerja Kelompok Dan Media Gambar dalam pembelajaran Tematik dengan tema bumi dan alam semesta subtema bagian bumi dan alam semesta tapi guru kurang memberi latihan-latihan soal. Sedangkan pengamatan terhadap siswa diperoleh data bahwa siswa kurang tertarik dengan materi yang diajarkan guru sehingga semua siswa dapat mencari mengenal bagian bumi dan alam semesta. Dalam kegiatan belajar kelompok siswa masih ada yang tidak aktif.

Setelah melaksanakan perbaikan siklus I mata pelajaran Tematik tema bumi dan alam semesta subtema bagian bumi dan alam semesta, yang dilaksanakan maka peneliti dan teman sejawat berdiskusi dan diperoleh data tentang refleksi sebagai berikut: (a) Guru dalam menyampaikan materi pembelajaran kurang menarik, sehingga siswa tidak antusias dalam kegiatan pembelajaran. (b) Sebagian besar siswa belum bisa menjelaskan sifat-sifat bangun datar. (c) Dalam kegiatan kerja kelompok belum kelihatan aktif, dan (d) Siswa belum berani bertanya tentang materi yang diajarkan. Dari data yang telah dipaparkan, dapat diketahui bahwa perbaikan pembelajarnan siklus I belum menunjukkan hasil yang maksimal atau masih gagal. Dari 23 siswa masih ada 5 siswa mendapat nilai diatas ketuntasan minimal atau 21,74\%, sedangkan yang mendapat nilai dibawah ketuntasan minimal adalah 18 siswa atau 78,26\%. Kegagalan atau ketidakberhasilan siklus I disebabkan karena: (a) Guru dalam menyampaikan materi pelajaran subtema bagian bumi dan alam semesta dengan alat peraga terlalu sedikit jadi siswa masih belum memahami dengan baik. (b) Guru dalam menyampaikan materi kurang memberi latihan-latihan Tema Bumi dan Alam Semesta. (c) Data dari hasil tes formatif siklus I adalah: (1) Dari 23 siswa yang semula hanya 5 siswa yang mendapat nilai diatas ketuntasan minimal menjadi 13 siswa atau 56,52\%; (2) Masih ada 10 siswa yang nilainya dibawah ketuntasan minimal atau 43,48\%; (3) Nilai rata-rata kelas mencapai 73,48.

\section{Deskripsi Siklus II}

Dari data pengamatan yang dilakukan oleh pengamat diketahui bahw guru telah melaksanakan proses belajar mengajar sesuai dengan rencana. Pada proses perbaikan pembelajaran siklus II ini guru sudah mengajar dengan menggunakan metode ceramah, tanya jawab, diskusi dan penerapan Metode Kerja Kelompok Dan Media Gambar pada subtema ketampakan rupa bumi. Dari pengamatan tentang siswa sudah kelihatan antusisias dalam mengikuti kegiatan belajar mengajar. Terbukti bila diberi pertanyaan Tema Bumi dan Alam Semesta siswa bisa menjawab dengan benar. Setelah melaksanakan perbaikan pembelajaran Siklus I mata pelajaran Tematik tema bumi dan alam semesta subtema ketampakan rupa bumi maka peneliti dan teman sejawat berdiskusi dan diperoleh data tentang refleksi sebagai berikut: (a) Guru dalam menyampaikan materi pelajaran kurang menarik, sehingga siswa tidak semangat dalam kegiatan pembelajaran. (b) Sebagian besar siswa belum bisa menjelaskan mengenal ketampakan rupa bumi. (c) Dalam kegiatan kerja kelompok siswa belum kelihatan aktif. (d) Siswa belum berani bertanya tentang materi yang diajarkan.

Setelah melaksanakan perbaikan pembelajaran Siklus II diperoleh hasil refleksi sebagai berikut; (a) Guru telah melaksanakan kegiatan pembelajaran sesuai dengan rencana. (b) Secara umum proses pembelajaran sudah baik. (c) Aktivitas siswa juga sudah menunjukkan perubahan lebih aktif. (d) Perolehan nilai hasil tes formatif sudah memenuhi kriteria keberhasilan. 
Dari hasil temuan dan refleksi pada perbaikan pembelajaran tentang bentuk ketampakan rupa bumi dan diketahui adanya peningkatan nilai hasil belajar siswa. Pada perbaikan pembelajaran Siklus I nilai rata-rata 73,48 sedangkan pada perbaikan pembelajaran Siklus II nilai rata-rata 83,48. Hal ini menunjukkan bahwa perbaikan pembelajaran Siklus II dapat lebih meningkatkan pemahaman siswa terhadap siswa terhadap materi yang diajarkan dengan penerapan metode kerja kelompok dan media gambar. Dalam perbaikan pembelajaran Siklus II siswa lebih aktif, lebih bersemangat dalam mengikuti kegiatan pembelajaran, sehingga suasana kelas lebih hidup. Dari analisa diatas dapat disimpulkan bahwa dari Siklus I ke Siklus II menunjukkan keberhasilan. Keberhasilan Siklus II dibuktikan dengan adanya: (a) Dalam kegiatan pembelajaran siswa terlihat aktif dalam kerja kelompok. (b) Sebagian besar siswa telah mampu menjawaab soal tes formatif Tema Bumi dan Alam Semesta. Setelah diadakan tes formatif hasilnya dari 23 siswa nilai rata-rata 83,48 .

\section{Pembahasan}

Untuk mencapai keberhasilan dalam proses belajar mengajar tidak mudah, sebab banyak faktor yang menjadi penyebab berhasil tidaknya proses pembelajaran. Dari berbagai kajian teori, faktor yang paling menentukan berhasil tidaknya proses belajar mengajar adalah kemampuan guru, terutama dalam memilih dan menggunakan strategi, metode, dan alat peraga yang sesuai dengan materi yang diajarkan. Pada penelitian ini, peneliti menekankan pada kemampuan guru dalam memilih strategi pembelajaran. Pra siklus dilakukan untuk mendapatkan data awal, yang digunakan sebagai acuan keberhasilan Siklus I dan Siklus II yang akan dilakukan.

Sebelum program perbaikan pembelajaran dilaksanakan, siswa kurang menguasai materi Tema Bumi dan Alam Semesta pada mata pelajaran Tematik. Hal ini disebabkan karena guru dalam kegiatan pembelajaran tidak menarik perhatian siswa karena menggunakan alat peraga yang terlalu kecil, sehingga siswa tidak begitu jelas. Guru juga kurang dalam memberi latihan-latihan soal tentang mengidentifikasi mengenal ketampakan rupa bumi. Dalam Penelitian Tindakan Kelasyang berawal dari kegiatan-kegiatan yang dialami guru dalam proses dan hasil belajar. Setelah peneliti berdiskusi dengan teman sejawat dan berkonsultasi dengan pembimbing, peneliti perlu mengadakan perbaikan Siklus I ini peneliti merancang perbaikan pembelelajaran dengan menitikberatkan pada penggunaan metode, penggunaan alat peraga, dan penerapan Metode Kerja Kelompok Dan Media Gambar untuk menarik perhatian siswa dan meningkatkan hasil belajar siswa walaupun belum seluruhnya tuntas, Siswa yang tuntas ada 13 dari 23 siswa atau 56,52\%. Setelah diadakan perbaikan pembelajaran Siklus I, dari 23 siswa ada 10 siswa yang mendapat nilai dibawah nilai ketuntasan minimal atau 41,67 \%. Hal tersebut yangkemudian menjadi perhatian peneliti untuk melakukan perbaikan pembelajaran Siklus II.

Ketercapaian tujuan pembelajaran ditentukan oleh beberapa faktor. Diantaranya faktor yang paling menentukan adalah kemampuan guru dalam mengelola kelas, metode, penggunaan alat peraga, dan penggunaan strategi pembelajaran. Pemilihan metode, alat peraga, dan strategi pembelajaran besar pengaruhnya terhadap keberhasilan proses pembelajaran. Penerapan strategi pembelajaran yang digunakan tentunya harus disesuaikan dengan materi pelajaran yang diajarkan.

Berdasarkan hasil dari perbaikan pembelajaran Siklus I, peneliti berdiskusi dengan teman sejawat dan berkonsultasi dengan pembimbing perlu mengadakan perbaikan pembelajaran Siklus II ini peneliti merancang pembelajaran dengan menitik beratkan 
pada kemampuan guru dalam membimbing siswa untuk mengidentifikasi mengenal ketampakan rupa bumi. Setelah diadakan tes formatif pada pembelajaran Siklus II dari 23 siswa sudah semua siswa yang mencapai nilai diatas tuntas atau 100\%. Dengan demikian dapat disimpulkan dengan menerapkan Metode Kerja Kelompok Dan Media Gambar, menggunakan metode diskusi, penggunaan media yang sesuai serta kesabaran yang diberikan guru dalam membimbing siswa untuk menjelaskan mengenal ketampakan rupa bumi pada mata pelajaran Tematik kelas III SD Negeri 2 Tete ternyata dapat meningkatkan hasil belajar siswa. Berikut hasil peningkatan belajar siswa.

Tabel 1. Hasil Ketuntasan Belajar Siswa Per Siklus

\begin{tabular}{|c|c|c|c|}
\hline Kategori & Pra Siklus & Siklus I & Siklus II \\
\hline Tuntas & 5 & 13 & 23 \\
\hline Tidak Tuntas & 18 & 10 & 0 \\
\hline Jumlah & 23 & 23 & 23 \\
\hline
\end{tabular}

Tindakan yang peneliti laksanakan, mentargetkan 100\% siswa mencapai KKM. Tetapi setelah selesai diadakan Penelitian Tindakan Kelas, ternyata hasil yang dicapai hanya 100\% siswa yang mencapai KKM. Hal ini disebabkan karena kedua siswa yang tidak mencapai $\mathrm{KKM}$, termasuk anak dengan kemampuan yang dibawah rata-rata (termasuk tertinggal di kelasnya). Karena dalam mata pelajaran yang lain pun, kedua siswa tersebut perlu bimbingan yang khusus, karena kedua siswa tersebut mempunyai masalah psikologis, sehingga perlu pendampingan khusus.

\section{Kesimpulan}

Berdasarkan hasil penelitian yang telah dilaksanakan dapat disimpulkan sebagai berikut; (1) Siswa menjadi lebih antusias dan termotivasi dalam belajar tematik; (2) Pada kelas III semester 2 SD Negeri 2 Tete yang berjumlah 23 siswa ternyata dari siklus ke siklus hasil belajar siswa mengalami peningkatan. Dari $21,74 \%$ siswa yang tuntas menjadi $56,52 \%$ pada siklus 1, kemudian pada siklus 2 meningkat menjadi 100\%; dan (3) Melalui penerapan metode kerja kelompok dan media gambar dalam pembelajaran, dapat meningkatkan hasil belajar siswa kelas III semester genap SD Negeri 2 Tete dengan prosentase ketuntasan $100 \%$.

\section{Saran}

Adapun saran yang dapat disampaikan berdasarkan hasil penelitian ini antara lain adalah (1) Guru dalam melaksanakan proses pembelajaran seharusnya memilih metode dan strategi yang sesuai dengan materi yang diajarkan sehingga proses pembelajaran semakin bermakna. (2) Untuk menunjang tercapainya keberhasilan maka pihak sekolah seharusnya dapat memberikan sarana dan prasarana yang memadai agar proses pembelajaran berlangsung dengan maksimal.

\section{Daftar Pustaka}

Achmad, H. (2018). Penggunaan Media Gambar untuk Meningkatkan Kemampuan Menulis Cerita Pendek Bahasa Inggris di SMAN 3 Mataram. Jurnal Kependidikan: Jurnal Hasil Penelitian dan Kajian Kepustakaan di Bidang Pendidikan, Pengajaran dan Pembelajaran, 4(1), 41-47. doi:https://doi.org/10.33394/jk.v4i1.900

Arifin, Zainal. (2017). Evaluasi Pembelajaran, Bandung: Rosdakarya. Gatot Muh. Setyo. (2018). Pembelajaran Matematika SD. Jakarta: UniversitasTerbuka. Hambali Julius, Siskandar. (2013). PendidikanMatematika I PGSD. Jakarta: Depdikbud 
Ismail. (2013). Kapita Selekta Pembelajaran Matematika. Jakarta: Universitas terbuka.

Jayanti, F., \& Fachrurazi, F. (2020). Peningkatan Keterampilan Menulis Karangan Deskripsi

Melalui Metode Discovery dengan Menggunakan Media Gambar pada Mahasiswa

Program Studi Pendidikan Bahasa dan Sastra Indonesia STKIP Pontianak. Jurnal

Kependidikan: Jurnal Hasil Penelitian dan Kajian Kepustakaan di Bidang

Pendidikan, Pengajaran dan Pembelajaran, 6(2), 329-339.

doi:https://doi.org/10.33394/jk.v6i2.2491

Karso. (2014). Pembelajaran Matematika I PGSD. Jakarta :Universitas Terbuka.

Nuryaningsih, W. (2021). Penerapan Media Schoology untuk Meningkatkan Motivasi dan

Hasil Belajar Siswa dalam Pembelajaran Bahasa Indonesia di SMP Negeri 3 Bojong Pekalongan. Jurnal Paedagogy, $\quad 8(1), \quad 16-23$. doi:https://doi.org/10.33394/jp.v8i1.3161

Papasi, J. (2020). Meningkatkan Motivasi Belajar Siswa dengan Menggunakan Metode Kerja Kelompok pada Mata Pelajaran Pendidikan Agama Kristen di SMP Negeri I Totikum Sulawesi Tengah. Jurnal Paedagogy, 7(4), 339-347. doi:https://doi.org/10.33394/jp.v7i4.2879

Sadirman. (2011). Interaksi dan Motivasi Belajar-Mengajar. Jakarta: Rajagrafindo Persada.

Suarni, G., Rizka, M., \& Zinnurain, Z. (2021). Analisis Pengaruh Penerapan Model Pembelajaran Sains Teknologi Masyarakat Terhadap Hasil Belajar Siswa. Jurnal Paedagogy, 8(1), 31-38. doi:https://doi.org/10.33394/jp.v8i1.3226

Sudjana, Nana. (2013). Belajar dan Pembelajaran. Bandung: Remaja Rosda Karya

Surodiana, S. (2020). Penerapan Media Permainan Sosiology Shot Traditional (SOSIS -T) untuk Meningkatkan Motivasi Belajar Sosiologi Siswa MAN 1 Lombok Timur. Jurnal Paedagogy, 7(4), 302-311. doi:https://doi.org/10.33394/jp.v7i4.2927 